\title{
UVODNIK
}

\section{VLOGA TERMINOLOGIJE V SODOBNEM VARNOSTNEM OKOLJU}

Prva številka Sodobnih vojaških izzivov $v$ tem letu je namenjena vojaški terminologiji. V dobrih dvajsetih letih izhajanja publikacije še nismo izdali tematske številke, ki bi posebej obravnavala to področje, čeprav se pri njegovem razvoju že vsa leta pojavljajo vprašanja in razprave o posameznih izrazih, pojmih, prevodih ter njihovem resničnem pomenu. Navedeno ne pomeni, da se s tem področjem $\mathrm{v}$ obrambnem resorju ni nihče ukvarjal. Prav nasprotno. Iz prispevkov boste bralci izvedeli veliko o zgodovini, organizaciji, razvoju, priložnostih in izzivih, s katerimi se srečujejo terminologi, lektorji, prevajalci, uredniki in ne nazadnje vsi drugi udeleženci, ne samo s področja obrambe, temveč tudi širše v slovenskem prostoru.

Avtorji prispevkov v tej številki pogosto omenjajo zgodovinski kontekst, v katerem se je razvijal slovenski jezik, s poudarkom na vojaški stroki. V povezavi s tem je pomembno omeniti, da ima slovenski vojaški jezik bogato zgodovino. Ob tej priložnosti se lahko spomnimo na majorja Andreja Komela pl. Sočebrana, ki je utemeljitelj slovenskega vojaškega jezika. Med drugim se je tudi trudil prevesti različne nemške vojaške izraze v slovenski jezik. Izdal je dve knjigi, leta 1884 Osnovo vojstva in leta 1890 Organizacijo vojstva, pri čemer se izraz vojstvo v današnjem strokovnem jeziku na področju varnosti, obrambe in vojske ni uveljavil. Leta 1996 je sicer na Ministrstvu za obrambo začela izhajati publikacija Vojstvo, vendar je to trajalo samo do leta 2000 . V povezavi $\mathrm{z}$ imenom te publikacije je $\mathrm{v}$ uvodu v prvo številko prof. dr. Tomo Korošec, strokovnjak za vojaško izrazoslovje, pojasnil vzroke za izbiro besede vojstvo kot ime publikacije. Utemeljil je, da je Komel nemški izraz za področje vojaštva odlično prevedel. Koren besede voj- s priponskimi obrazili, kot so -ak (vojak), -na (vojna), -ska (vojska), -aštvo (vojaštvo), in njegovi pridevniški izpeljanki, torej vojaški, vojen, »in celo, kar zajema specializiran izraz obramba itn., lahko enoumno poimenujemo z izrazom vojstvo, « je sklenil Korošec na tretji strani prve številke Vojstva. 
Žal se nista ohranila niti izraz vojstvo kot tudi ne obstoj publikacije s tem imenom. $\mathrm{Na}$ količino in raznovrstnost izzivov za vojaško izrazoslovje so pomembno vplivali vključevanje Republike Slovenije v mednarodno varnostno okolje in tudi želja ter potreba po poenotenju vojaških strokovnih izrazov zaradi boljše organizacije in učinkovitosti skupnega delovanja.

V prispevku Tine Pečovnik Sodobni trendi v slovenski vojaški terminologiji spoznamo postopke, merila in zakonitosti pri vzpostavljanju standardov ter interakcije z drugimi terminologi in ustanovami v Sloveniji. Avtorica tipološko razvrsti novejše slovenske vojaške termine in poudari potrebo po bolj sistematičnem pridobivanju ter preučevanju terminologije. Pri tem izpostavi zahtevne terminološke izbire med pojmi, kot so usmerjevalec ali kontrolor združenih ognjev, zrakoplov ali letalnik ter generalka, generalica ali generalinja

Standardizaciji slovenske vojaške terminologije se je posvetila Tamara Derman Zadravec. V prispevku podrobno pojasni, kaj pomeni pojem standardizacija, kako ta poteka in zakaj jo potrebujemo v slovenskem okolju. Pojasni razloge, zaradi katerih je zelo pomembna pri našem sodelovanju z drugimi državami članicami zavezništva in za zavezništvo ter predstavi smernice prihodnjega razvoja slovenske vojaške terminologije.

Ana Hazler v prispevku Upravljanje terminologije v slovenskem vojaškem okolju in primeri dobre prakse podrobno razloži, kako je potekalo in še poteka delo prevajalcev in terminologov v obrambnem sistemu ter Slovenski vojski. Natančneje predstavi predloge poteka dela $\mathrm{v}$ prihodnosti, ki temeljijo na ugotovitvah, pridobljenih $\mathrm{s}$ primerjalno analizo med drugimi državami članicami zavezništva na področju razvijanja vojaške terminologije.

Ne-/utemeljenost terminološke intervencije pri terminu zrakoplov je naslov prispevka Vanese Škornik, ki prikazuje različne vidike in razsežnosti izzivov, s katerimi se srečujejo jezikoslovci, lektorji, prevajalci in drugi vsebinski nosilci na področju varnosti, obrambe in vojaštva pa tudi drugi, kot so na primer letalci ali jadralci. Katera je prava izbira pri rabi teh dveh izrazov in kako jo utemeljiti? Več v prispevku.

O standardizaciji v Natu, ki je pomembna za slovensko sodelovanje z drugimi državami članicami zavezništva, piše Rafael Kolbl v prispevku Standardizacija in terminologija v Natu - vloga centrov odličnosti. Tudi Natov center odličnosti za gorsko bojevanje v Republiki Sloveniji se spoprijema z različnimi izzivi na področju vojaške terminologije. Avtor v prispevku predstavlja raznovrstno razumevanje pojma gorovje (angl. mountains), ki ima v zemljepisnem smislu v državah in pokrajinah različno nadmorsko višino (hribi, griči itn.) in posledično drugačen pristop pri bojevanju.

Študijo primera, kako prevesti in posledično ustrezno pojmovno opredeliti določeno vsebino, sta pripravili Nina Raduha in Iris Žnidarič v prispevku Terminologija 
kot ključni gradnik obrambno-vojaške stroke - primer Natovega koncepta strateških komunikacij. Pogosto samo prevod ne omogoča vsebinsko ustreznega izraza, kar pomeni, da ga je treba poiskati. Kadar tak izraz že obstaja in pomeni nekaj drugega, na nekem drugem področju podobnega, postane izziv še toliko zanimivejši.

Mojca Pešec v prispevku Vpliv razvoja umetne inteligence na nacionalno varnost pojasni terminologijo in definicijo umetne inteligence, kaj ta pojem obsega in kdaj se pojavlja na področju varnosti. Definicij in pojavnih oblik je veliko na več področjih. Nekatere izmed njih so še posebej zanimive za obrambne in varnostne sisteme ter oborožene sile, zato bo treba $\mathrm{v}$ prihodnosti terminologiji in sistemom umetne inteligence na obrambno-varnostnemu področju nameniti še več pozornosti.

Kaj pomeni izraz strategija in kakšne so razlike $\mathrm{v}$ rabi tega termina glede na znanstvene vede in področja raziskovanja, kaj pomeni izraz vojaška strategija in v čem se loči od politične? Gre za teorijo ali prakso strategije? Kakšen pomen so imele strategije v zgodovini, kaj pomenijo danes in kako bo s tem terminom v prihodnosti, je raziskoval Pavel Vuk v prispevku Izzivi vojaške strategije v 21. stoletju.

V tej številki je veliko več avtoric kot avtorjev. Leta 2020 mineva 20 let od sprejetja Resolucije Varnostnega sveta Združenih narodov 1325, ki je posvečena ženskam, miru in varnosti. Razmerje med avtoricami in avtorji $\mathrm{v}$ tej številki je povsem naključno in ni z ničimer povezano s to obletnico. Morda pa je vseeno mogoče, da je področje terminologije bolj zanimivo za ženske, še posebej, kadar se odločajo za izbiro poklica? 